\title{
Organization of the integrated control of the implementation of sophisticated construction projects
}

\author{
Dmitriy Leybman, Sergey Sborshchikov* and Elizaveta Kochenkova \\ Moscow State University of Civil Engineering, Yaroslavskoe shosse, 26, Moscow, 129337, Russia
}

\begin{abstract}
A successful implementation of the investment programs and projects is mainly determined by an effective organizational control circuit. This is the circuit, which includes a construction organizer (external engineering company), carrying out a set of management work, based on timely and reasonable decision-making at the design and construction stages.
\end{abstract}

\section{Methods}

There are three variants (fig.1) of including at the corporate level a construction organizer into the structure of the implementation of the investment-construction activity with programs and projects (so-called project management):

Variant 1 - an engineering company carries out its activity in the form of a project office, and a conventional control circuit with the main contractor operates at the building object level;

Variant 2 - an engineering company manages the construction of a certain object, participating as one of the executors of the work of the project office, which is managed by the client's operating unit;

Variant 3 - an engineering company manages the project office, and its units retranslates and specifies on-site managerial calls.

\footnotetext{
${ }^{*}$ Corresponding author: Tous2004@mail.ru
} 


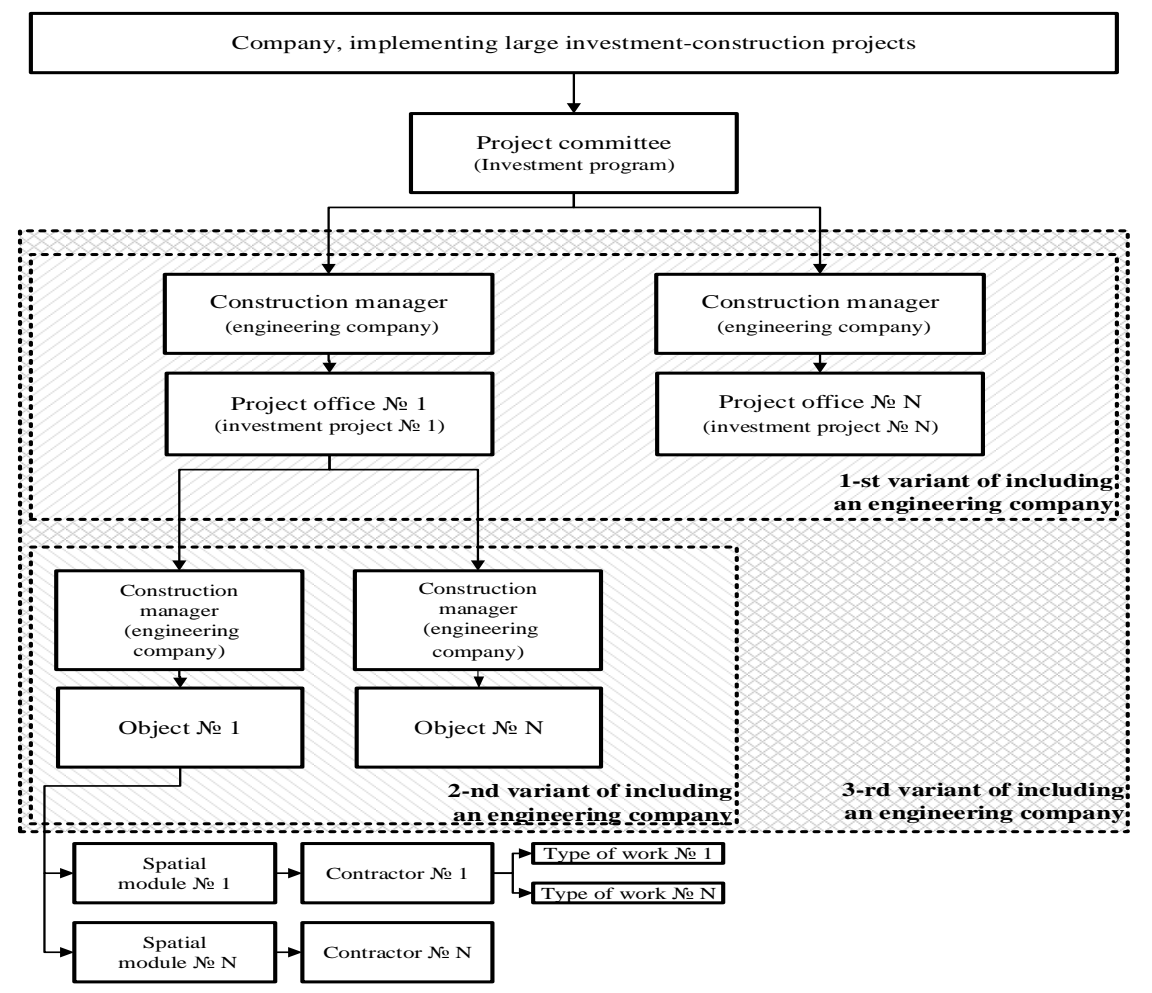

Fig. 1. - Variants of implementation of the integrated control, based on the engineering investment program management scheme

It may be claimed, that the source of efficiency improvement of large investment projects, including construction of the unique and sophisticated facilities, main structural element of the engineering management scheme, is an integrated control of the project implementation. This control has its own functional decomposition and encompasses a sequence of the planning procedures, monitoring and correction of decisions in the horizontal direction and provides a single strategic and operative control vector to the investment-construction activity at the enterprise level in the vertical direction.

Both vertical and horizontal axes of the integrated control imply the presence of active and passive components.

A passive component involves representing the values of the resulting indicators, the degree of their deviation from the planned ones, and an active component is connected with determination of the reasons of deviations and formulation of measures for their damping and evening-out.

In accordance with the methodology and common practice investment projects may be identified, taking into account a progress level in a certain period and possibility of completion in the next one. For this reason, they may be classified as the new and previously approved ones.

In this regard, it should be pointed out, that a previously approved project may get a new estimate as a result of monitoring the implementation of works at the beginning of a new period within the framework of the integrated control, that will require recalculation of the resources provision and development of recommendations for adjusting resources and 
competences allocation between the facilities (implementation of the procedures of the active component of the integrated control).

When formulating such recommendations in the next period, not only restrictions, connected with the progress level of the previously approved projects, but also a safety margin should be taken into account.

It is necessary to mention, that organizational and technical restrictions may be represented as the ratio between the amount of investment or resources and competences allocation at different stages, between the scope of work for each implemented project.

Technically, resources and competences allocation between projects is carried out in accordance with their priorities (importance) and with considering the resource limit in this period.

In this regard, it is very important to correctly assess the level of implementation of the planned indicators, determined by the title of objects and their procedural nomenclature, in the procedure of formulating the recommendations for adjusting the resource provision of the investment projects.

It is also necessary to take into consideration an influence on the execution of work of random factors, not taken into account when forming an investment project implementation plan. For this reason, a task of determination of the probability of deviation of actual indicators from the planned ones appears at the integrated control of work implementation (provision of passive component procedures).

\section{Results}

The solution of this task may be described by the following strategic controlling scheme:

1) a maximum probability of execution of work by all investment projects is determined;

2) a maximum probability of achieving the planned values of the certain work groups, indicators or investment projects is determined;

3) the adjusted indicators are correlated with the rest parameters, a probability of implementing the investment project implementation plan in general is determined.

The recommendations for adjusting the resource provision and competences allocation within the framework of the integrated control of the implication of the investment projects are based on the adopted strategy of resources and competences concentration and periodic priority verification.

The investment projects implementation may assume two strategies of the resources and competences concentration: partial and total one.

In case of total concentration resources are firstly directed to the more priority investment projects, then - to the less priority ones, so that high priority projects immediately receive the necessary amount of resources, and less priority ones receive just a remainder, which may not be enough to complete the work.

Partial concentration involves allocating resources not immediately, but from a certain period, i.e. they are concentrated only on some investment projects at certain moments depending on the priority and profitability, this strategy less restricts the maneuver of resources and competences.

The prioritization may be subjected to the following rules:

1) the priority increases with approaching deadline for the investment period and commissioning of an object;

2) the priority of an investment project is correlated with an expected useful effect (commercial or non-commercial). 
A day-to-day management, implemented in a unified style with the strategic one, within the framework of the integrated control of the implication of the investment projects, connected with the resources and competences allocation, may be represented in the form of the following enlarged groups of procedures:

1) prioritization and determination of the necessary level of investments for each project;

2) resources and competences allocation between the investment projects, according to their priority;

3) determination of the integrated efficiency indicators of the investment projects and whole program in general with considering the adjustment of the resources and competences allocation.

A method of day-to-day management within the framework of the integrated control of the construction of sophisticated facilities may be represented in the following formalized form.

1. Processing and generation of initial data.

2. Formation of a cycle for revising the priority of the investment projects $0<\mathrm{P}<\mathrm{K}$ and a periods busting cycle $1<\mathrm{IP}<\mathrm{L}$.

3. Investment project selection for providing them with resources. Only unfinished projects are used in this procedure. Progress level check on the selected projects.

4. Priority ranking of projects.

4.1. If there is no need for priority adjustment, then p.4.2 is performed, otherwise prioritization of the investment project is carried out, according to the following criteria:

- importance (of especial importance, important, common);

- $\quad$ investment stage duration (previously approved, overdue, new).

4.2. Ranking of the investment projects, selected for implementation at a specific period according to prioritization, is carried out.

5. Determination of the planned demand for resources of the project office in the absence of a negative outlook on the achievement of investment project completion deadlines, according to the extension of ALF implementation - for overdue projects. This procedure paragraph is connected with determination of the following data:

$\mathrm{V}_{1}(\mathrm{~N})$ - a planned amount of resources for the $\mathrm{N}$-th project office (investment project).

$\mathrm{V}_{0}(\mathrm{~N})$-made available, assimilated and cash resources of the $\mathrm{N}$-th project office. This indicator is established from the initial data for new investment projects, and it is calculated in the p.8 for previously approved and overdue projects.

$\mathrm{D}(\mathrm{N} ; \mathrm{NP})$ - not assimilated at the beginning of this period (NP - month of the beginning of the period), but made available for the $\mathrm{N}$-th project office resources. It is determined on the basis of p.11 and 12 .

$\mathrm{SR}(\mathrm{N})$ - time to the $\mathrm{N}$-th project completion.

5.1. Determination of the necessary resource provision of the $\mathrm{N}$-th project office assumes three variants.

Variant 1 - in case, when the amount of made available at the beginning of the period $\mathrm{NP}$ resources is enough for execution of the due work $\mathrm{V}_{0}(\mathrm{~N} ; \mathrm{IP}) \geq \mathrm{D}(\mathrm{N} ; \mathrm{NP})$, taking into account the pace of the resource development and time to the $\mathrm{N}$-th project completion, necessary resource provision is determined as $\mathrm{V}_{1}(\mathrm{~N})=\mathrm{D}(\mathrm{N} ; \mathrm{NP})$.

Variant 2 - the case, assuming additional resource allocation. The procedure is carried out, when the amount of made available resources is not enough for completion of IP period works on time $\mathrm{V}_{0}(\mathrm{~N}$; IP) $<\mathrm{D}(\mathrm{N} ; \mathrm{NP})$ and $\mathrm{SR}(\mathrm{N})>\mathrm{R}$, and project office needs additional resources $\mathrm{V}_{1}(\mathrm{~N})=\mathrm{D}(\mathrm{N} ; \mathrm{NP})-\mathrm{V}_{0}(\mathrm{~N} ; \mathrm{IP})$.

Variant 3 - extension of the investment project implementation: in case, when the amount of made available resources is not enough for the investment project execution on time and time to completion is less, then time for allocation and transfer of the additional 
resources $\mathrm{SR}(\mathrm{N})<\mathrm{R}$, the deadline for completion of these work of the investment project is necessary to extend $\mathrm{SR}(\mathrm{N})=\mathrm{ALF}$ and the accepted condition is checked again.

6. A productivity increase ratio may be applied to increase reliability of the investment project $-\mathrm{DR}$, then $\mathrm{V}_{1}(\mathrm{~N})=\mathrm{V}_{1}(\mathrm{~N}) \times(1+\mathrm{DR})$. The priority and importance of the investment project may influence the DR value.

7. Determination of the total necessary amount of resources of the project office: it should not be more than the allocated limits of this period $\operatorname{SPM}(\mathrm{IP})=\sum_{\mathrm{N}} \mathrm{V}_{1}(\mathrm{~N}) \leq \mathrm{Q}_{\text {limit. }}$.

8. Resource allocation between project offices within the framework of the investment program is carried out depending on the need:

$$
\mathrm{VSR}=\frac{\sum_{\mathrm{x}=\mathrm{NP}}^{\mathrm{x}=\mathrm{KP}} \mathrm{V}_{1}(\mathrm{~N})}{\mathrm{FP}(\mathrm{IP})},
$$

where FP(IP) - number of months in this period.

8.1. Determination of the unencumbered resources (balance, stocks) - D after satisfaction of needs of the N-th project office:

$$
D=V S R-\sum_{K=1}^{N=1} V(K ; I P)-V_{1}(N),
$$

where V(N;IP) - actually allocated amount of resources to the N-th project office at the IP-th period; D - resource balance after satisfaction of needs of the N-th investment project (project office).

8.2. Additional investment of the project office is carried out in case, when $D>0$, if not all made available resources are yet allocated and there is an opportunity to completely meet resource needs of the $\mathrm{N}$-th project office $\mathrm{V}(\mathrm{N} ; \mathrm{IP})=\mathrm{V}_{1}(\mathrm{~N})$ and move on to the next project office. If the list of investment projects is over, then move to the next paragraph.

\subsection{End of the procedure, resources are completely allocated.}

9. An external cycle of the number of months in a period and an internal cycle of the amount of selected for execution in this period works of the investment project are formed to determine the resource requirements of certain works. $F(N ; j ; i ; x)=0$, if the $j$-th work of the $\mathrm{N}$-th project office (investment project) in the $\mathrm{x}$-th (its number) month of the period does not receive this type of resources.

10. Resource allocation by months between separate works of each investment project.

10.1. There are two possible typical cases, if additional resources have been allocated for the investment project works in the period. Case 1 - works, from which the resources are removed $\mathrm{V}(\mathrm{N} ; \mathrm{j} ; \mathrm{i} ; \mathrm{IP})\left\langle\mathrm{V}_{0}(\mathrm{~N} ; \mathrm{j} ; \mathrm{i} ; \mathrm{IP})\right.$, case 2 - works, for which additional resources are supplied or their amount does not change in this month of a period $\mathrm{V}(\mathrm{N} ; \mathrm{j} ; \mathrm{i} ; \mathrm{IP}) \geq \mathrm{V}_{0}(\mathrm{~N} ; \mathrm{j} ; \mathrm{i} ; \mathrm{IP})$.

In case 1: works of the $\mathrm{N}$-th investment project possess the necessary amount of the i-yh type resources $\mathrm{V}(\mathrm{N} ; \mathrm{j} ; \mathrm{i} ; \mathrm{IP})$, and their surplus $\mathrm{V}_{0}(\mathrm{~N} ; \mathrm{j} ; \mathrm{i} ; \mathrm{IP})-\mathrm{V}(\mathrm{N} ; \mathrm{j} ; \mathrm{i} ; \mathrm{IP})$ are directed to the works, that need them. Wherein such a surplus are in a state of reallocation for a R-period $\mathrm{F}(\mathrm{N} ; \mathrm{j} ; \mathrm{i})=\mathrm{V}(\mathrm{N} ; \mathrm{j} ; \mathrm{i} ; \mathrm{IP})$

In case 2: the works of an investment project, for which additional resources are 
supplied, possess an amount of resources $\mathrm{V}_{0}(\mathrm{~N} ; \mathrm{j} ; \mathrm{i} ; \mathrm{IP})$ for a R-period, in the remaining time FP(IP) - R these works already possess together with the supplied ones the necessary amount of resources $\mathrm{V}(\mathrm{N} ; \mathrm{j} ; \mathrm{i} ; \mathrm{IP})$. In this case the following states are typical:

a) before the resource supply, for a R-period: $F(N ; j ; i ; N P)=V_{0}(N ; j ; i ; I P)$;

b) after the resource supply FP(IP)-R: $F(N ; j ; i ; N P+R)=V(N ; j ; i ; I P)$.

10.2. If the $\mathrm{i}$-th type resource supply for the $\mathrm{j}$-th work of the $\mathrm{N}$-th investment project does not happen, then $\mathrm{F}(\mathrm{N} ; \mathrm{j} ; \mathrm{i} ; \mathrm{x})=\mathrm{Vo}(\mathrm{N} ; \mathrm{j} ; \mathrm{i} ; \mathrm{IP})$.

11. Calculation of the $\mathrm{i}$-th resource surplus for the $\mathrm{j}$-th work of the $\mathrm{N}$-th investment project by the beginning of the next month $-\mathrm{D}(\mathrm{N} ; \mathrm{j} ; \mathrm{i} ; \mathrm{x}+1)$, and after the $\mathrm{x}$-th month of work for a IP-period - D $(N ; j ; i ; x+1)=D(N ; j ; i ; x)-F(N ; j ; i ; x)$.

12. Execution check of the $\mathrm{j}$-th work in the $\mathrm{x}$-th month of a IP-period. If $\mathrm{D}(\mathrm{N} ; \mathrm{j}$; $\mathrm{i} ; \mathrm{x}+1) \leq 0$, then this work is executed. The mastered amount of the $\mathrm{i}$-th resource type as a result of the $\mathrm{j}$-th work execution for the $\mathrm{x}$-th month of the IP-period is taken equal to $\mathrm{D}(\mathrm{N} ; \mathrm{j} ; \mathrm{i} ; \mathrm{x})$. If $\mathrm{D}(\mathrm{N} ; \mathrm{j} ; \mathrm{i} ; \mathrm{x})<0$, then $\mathrm{F}(\mathrm{N} ; \mathrm{j} ; \mathrm{i} ; \mathrm{x})=\mathrm{D}(\mathrm{N} ; \mathrm{j} ; \mathrm{i} ; \mathrm{x})$.

13. Calculation for the $\mathrm{x}$-th month for all project offices (investment projects), transition to the next month $x=x+1$ of the period IP and to the p.9. If the period IP is ober, then proceed to the p.14.

14. If the calculation for the period is over, then proceed to the next period $\mathrm{IP}=\mathrm{IP}+1$ and to the p. 2 for calculation for the next period.

15. Calculation of the integrated efficiency indicators of both the project office and project committee: net present value, yield index, internal rate of return.

16. Formation of the resulting efficiency indicators, resource allocation by periods between works and projects of the investment program.

It is seen, that tree blocks may be distinguished in the structure of this model, and it corresponds to the methodology of the integrated control, described above:

1) from 1 to 8 paragraphs - strategic controlling block;

2) from 9 to 14 paragraphs - operative management block;

3) from 15 to 16 paragraphs - block of determination of the integrated efficiency indicators of the project committee's (investment program's) and some project office's (investment project's) activity.

\section{Conclusion}

The description of the integrated control procedures of the resource provision of the project committee and project offices management shows an opportunity of using the basic principles of the logistics methodology and representing these processes through the prism of the regulatory flows and resources management in the investment-construction field at the corporate level and becomes a starting point for further research in this direction.

\section{References}

1. Sborshchikov S. B. Logistika reguliruyushchikh vozdeystviy $\mathrm{v}$ investitsionnostroitel'noy sfere (teoriya, metodologiya, praktika): diss. dok. ekonom. nauk [Logistics of the regulatory impacts in an investment-constriction field (theory, methodology, 
practice): thesis of doctor of economic sciences], text; Rossiyskaya ekonomicheskaya akademiya im. G. V. Plekhanova [Pleckhanov Russian university of Economics]. - M., (2012). - p. 305

2. Khripko T.V. Osobennosti realizatsii protsedur otsenki i otbora predlozheniy kontragentov $\mathrm{v}$ usloviyakh inzhiniringovoy skhemy upravleniya stroitel'stvom [Features of the implementation of evaluation and selection of counterparty proposals procedures in the conditions of the engineering construction management scheme]; BST: Byulleten' stroitel'noy tekhniki [BST - Bulletin of Construction Equipment]. (2017). no. 12 (1000). pp. 40-41.

3. Leybman D.M. Parametricheskaya model' funktsionirovaniya sistemy strategicheskogo kontrollinga stroitel'stva unikal'nykh i tekhnicheski slozhnykh ob"yektov [Parametric model of the functioning of strategic controlling of unique and sophisticated facility construction]; Problemy sotsial'no-ekonomicheskogo razvitiya Sibiri [Issues of Social Economic Development of Siberia]. (2017). no. 4 (30). pp. 72-77.

4. Shinkareva G.N. and others. Otsenka effektivnosti upravleniya realizatsiyey stroitel'nogo proyekta $\mathrm{v}$ usloviyakh vozdeystviya sluchaynykh faktorov [Evaluation of the efficiency of the construction project implementation management under the influence of random factors];Vestnik MGSU[Proceedings of the Moscow State University of Civil Engineering]. (2017). v. 12. no. 11 (110). pp. 1240-1247.

5. Leybman D.M. Svyazi v sisteme strategicheskogo kontrollinga kak osnova obespecheniya effektivnogo kontura upravleniya investitsionno-stroitel'noy deyatel'nost'yu na korporativnom urovne [Connections in the strategic controlling system as the basis for ensuring an effective control loop of the investment-construction activity at the corporate level]; Vestnik Belgorodskogo gosudarstvennogo tekhnologicheskogo universiteta im. V.G. Shukhova [Proceedings of the Belgorod State Technological University named after V.G.Shukhov]. (2018). no.1. pp. 111-116.

6. Leybman D.M. Strategicheskiy kontrolling - instrument obespecheniya ustoychivogo razvitiya investitsionno-stroitel'noy deyatel'nosti [Strategic controlling is an instrument of ensuring the sustainability of the investment-construction field]; Vestnik Belgorodskogo gosudarstvennogo tekhnologicheskogo universiteta im. V.G. Shukhova [Proceedings of the Belgorod State Technological University named after V.G.Shukhov]. (2018).no. 2. pp. 88-93ю

7. Lazareva N.V. and others. Ustoychivoye razvitiye investitsionno-stroitel'noy deyatel'nosti $\mathrm{v}$ energeticheskom sektore [Sustainability of the investment-construction field in the energy industry]; Vestnik grazhdanskikh inzhenerov [Bulletin of civil engineers]. (2018). no. 2 (67). pp. 269-275.

8. Zharov YA.V. Uchet organizatsionnykh aspektov pri planirovanii stroitel'nogo proizvodstva $\mathrm{v}$ energetike [Consideration of the organizational aspects in planning of energy sector construction] Zhurnal PGS [Industrial and civil engineering]. (2013). no. 5. pp. 69-71.

9. Aleksanin A.V. Perspektivnyye napravleniya razvitiya organizatsii stroitel'stva [Prospective directions of the organization of construction]; Nauchnoye obozreniye [Scientific Review]. - (2015). - no. 10-1. - pp. 378-381.

10. Lyapin A.V., Lyapin V.YU. Sovremennyy podkhod k organizatsii smetnoy deyatel'nosti $\mathrm{v}$ stroitel'stve [Modern approach to the estimated activity management in construction]. Text. Nauchnoye obozreniye [Scientific Review]. - (2016). - no. 8. - pp. 251-255.

11. Zhuravlev P.A. K voprosu ispol'zovaniya resursno-tekhnologicheskogo modelirovaniya pri formirovanii investitsionnykh program [To the issue of using resource-technological models in the formation of investment programs]. Text. Vestnik Belgorodskogo gosudarstvennogo tekhnologicheskogo universiteta im. V.G. Shukhova (Proceedings of 
the Belgorod State Technological University named after V.G.Shukhov) - (2017). - no. 7. - pp. 198-201.

12. Lazareva N.V., Bakhus Ye.Ye. K voprosu effektivnosti obespecheniya kachestva stroitel'noy produktsii [To the issue of quality assurance efficiency of construction]. Text. // Nauchno-teoreticheskiy zhurnal Vestnik BGTU im. V.G. Shukhova [Proceedings of the Belgorod State Technological University named after V.G.Shukhov]. no. 12, (2017), pp. 220-225.

13. Lazareva N.V. Stoimostnoy inzhiniring kak osnova integratsii protsessov planirovaniya, finansirovaniya i tsenoobrazovaniya $\mathrm{v}$ investitsionno-stroitel'noy deyatel'nosti [Cost engineering as the base of integration of the planning, financing and pricing processes in the investment-construction activity]. Text. Vestnik MGSU [Proceedings of the Moscow State University of Civil Engineering]. - (2015). - no. 11. - pp. 178-185.

14. Zhuravlev P.A. Tsena stroitel'stva i etapy yeye formirovaniya [The construction value and the stages of its formation]. Text. Vestnik Irkutskogo gosudarstvennogo tekhnicheskogo universiteta [Proceedings of the Irkutsk National Research Technical University]. (2015). - no. 9 (104). - pp. 174-178. 